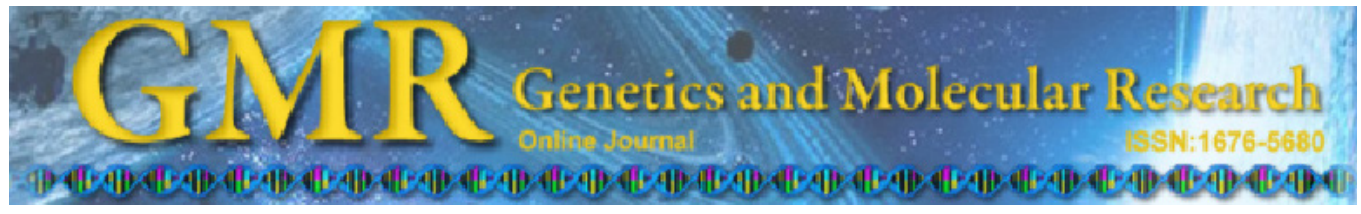

Short Communication

\title{
Confirmation of a purple-leaved plum graft hybrid
}

\author{
X.M. Zhou ${ }^{1}$, Y.S. Liu ${ }^{1}$ and X.J. Li $^{2}$ \\ ${ }^{1}$ School of Horticulture Landscape Architecture, \\ Henan Institute of Science and Technology, Xinxiang, China \\ ${ }^{2}$ Department of Life Science and Technology, \\ Henan Institute of Science and Technology, Xinxiang, China \\ Corresponding authors: Y.S. Liu / X.J. Li \\ E-mail: ysliu63@yahoo.ca / x_j_li@yahoo.com
}

Genet. Mol. Res. 12 (1): 710-713 (2013)

Received July 18, 2012

Accepted October 30, 2012

Published March 11, 2013

DOI http://dx.doi.org/10.4238/2013.March.11.19

\begin{abstract}
Fifty-seven scions from an adult purple-leaved plum tree were grafted onto the crown of a 6-year-old Yuhuang plum tree and compared to the control of a non-grafted tree. The floral buds of the purple-leaved plum were fully removed before blossoming to avoid sexual hybridization between the two species. The seeds of the Yuhuang plum were picked in July and sown in the spring after stratification. Three, eleven and eight variants with purplish red leaves were found among the seedlings that grew from the seeds picked in 1999, 2000, and 2001, respectively. The ratio of variant occurrence ranged from 2.3 to $15.8 \%$. Our results confirmed the observation of a graft hybrid by Luther Burbank.
\end{abstract}

Key words: Darwin; Graft hybrid; Graft-induced changes; Plum 


\section{INTRODUCTION}

Although there are many records of graft-induced genetic changes in ancient China (Liu, 2006), Darwin, in 1868, was the first to put forward the concept of graft hybrids, that is, individuals produced from cellular tissue of the stock and the scion. Unfortunately, the Darwinian notion of graft hybrids never gained wide acceptance because it was assumed that genetic material is not exchanged between the stock and scion. Thus, the existence of graft hybrids was not accepted, and these hybrids were regarded only as a type of chimera. Over the past century, however, the existence of graft hybrids has been confirmed by several independent groups of scientists (Michurin, 1949; Taller et al., 1999; Liu, 2006). An intriguing observation was made by the great horticulturist, Luther Burbank, who grafted a twig of a purpleleaved plum onto an old Kelsey plum tree in 1893. The seeds gathered from the Kelsey plum tree were sown in the next season, and one seedling with deep purple leaves was obtained among the seedlings. He believed that the seedling was a graft hybrid between purple-leaved plum and Kelsey plum. There was no other purple-leaved plum within thousands of miles. Furthermore, the scion had not bloomed, and hence, crossing could not have occurred through ordinary means (Burbank, 1914-1915).

\section{MATERIAL AND METHODS}

To confirm the observation by Burbank, we grafted 57 scions (twigs) from an adult purple-leaved plum tree (Prunus ceraifera cv. Pissardii) onto the crown of a 6-year-old Yuhuang plum tree (Prunus salicina Lindl) in March 1998 (Figure 1).

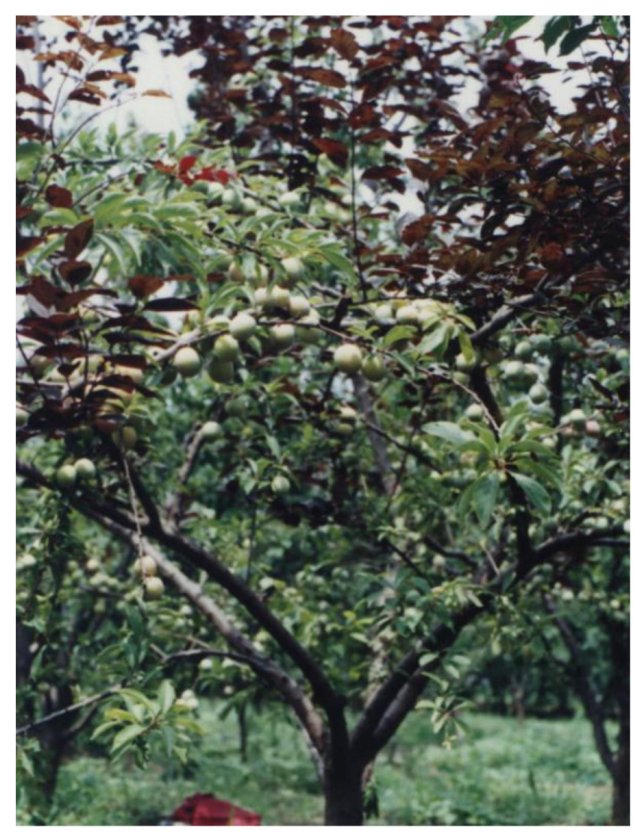

Figure 1. Scions of purple-leaved plum were grafted onto the crown of Yuhuang plum tree. 
A non-grafted Yuhuang plum tree nearby served as a control. These trees were under open pollination and were grown in the private orchard of Zhixing Li in Gucun, approximately $15 \mathrm{~km}$ from Hui County, Henan Province. The floral buds of the purple-leaved plum were fully removed before blossoming to avoid sexual hybridization between the two species. The seeds of the Yuhuang plum were picked in July and sown in the next spring after stratification.

\section{RESULTS AND DISCUSSION}

No obvious changes were observed among the seedlings that grew from the seeds picked in 1998 and sown in 1999. However, remarkably, three variants with purplish red leaves were found among the 19 seedlings that grew from the seeds picked in 1999 and sown in 2000. Moreover, 11 and 8 variants with purplish red leaves were also found among the 477 and 163 seedlings that grew from seeds picked in 2000 and 2001, respectively (Table 1 and Figure 2). It should be noted that obvious changes had never been observed since 1998, either in the stock of the Yuhuang plum tree on which the scions of the purple-leaved plum had been grafted or in the seedlings that grew from the seeds of the control of the non-grafted Yuhuang plum tree.

Table 1. Variants among the seedlings of grafted and non-grafted Yuhuang plum.

\begin{tabular}{llccr}
\hline Year & Treatments & Seedlings & Variants (purple-leaved) & Variant rate (\%) \\
\hline 1999 & Grafted & 126 & 0 & 0.0 \\
& Non-grafted & 98 & 0 & 0.0 \\
2000 & Grafted & 19 & 3 & 15.8 \\
& Non-grafted & 109 & 0 & 0.0 \\
2001 & Grafted & 477 & 11 & 2.3 \\
& Non-grafted & 115 & 0 & 0.0 \\
& Grafted & 163 & 8 & 4.9 \\
& Non-grafted & 107 & 0 & 0.0 \\
\hline
\end{tabular}

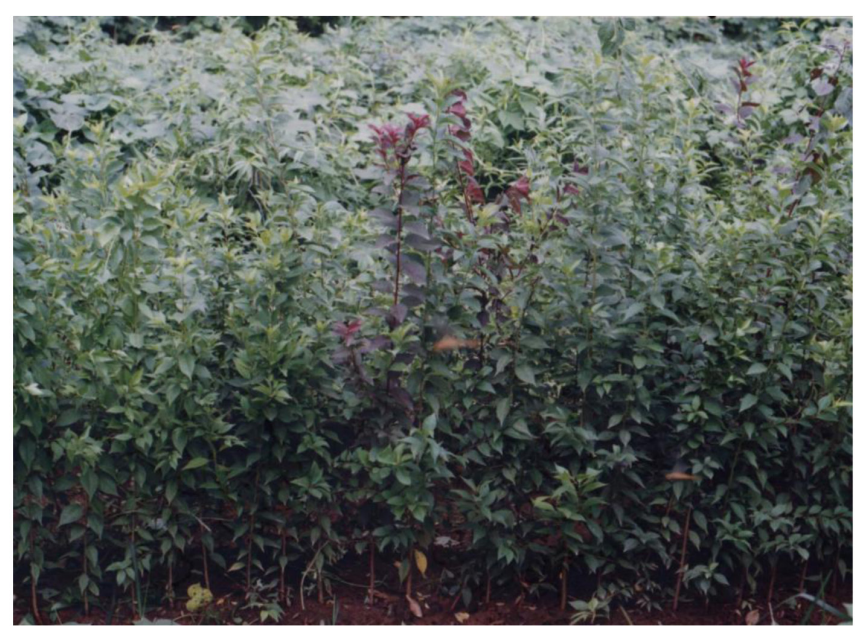

Figure 2. Seedling of the "Yuhuang" plum on which the purple-leaved plum were grafted. Some purple-leaved variants were found among the seedlings. 
Our results confirmed the observation that Burbank noted in 1893. Our results may be thought to be attributed to mutation or contamination. However, in our experiments, the variant rate of the Yuhuang plum seeds was as high as 2.3 to $15.8 \%$, much higher than the mutation rate. The possibility of accidental fertilization by purple-leaved plum pollen could be rejected because the floral buds of the purple-leaved plum were fully removed before blossoming, and a control tree was used for comparison. In addition, the possible contamination from bees, which could bring another source of purple-leaved plum, was not feasible because bees fly as far as $12 \mathrm{~km}$, and foraging is typically limited to food sources within $3 \mathrm{~km}$. In contrast, our experimental trees are located approximately $15 \mathrm{~km}$ from Hui county, which is the closest source of purple-leaved trees. To explain the formation of graft hybrids, Darwin (1868) proposed that cells are capable of secreting gemmules (molecular carriers of hereditary characters and the embryonic form of our modern genes). These gemmules are able to freely diffuse from cell to cell. For grafts, such diffusion occurs between the cells of the stock and the scion. Michurin (1949) also deduced that genes might move between the stock and the scion. There is now evidence that DNA moves freely throughout a plant (Gahan, 2003), and recently, Kanehira et al. (2010) demonstrated that some mRNAs can move from the rootstock to the scion through the graft union in apple trees. With the ability of the circulating DNA and RNA to enter cells to modify the biology of the recipient cells, it is reasonable to suggest that graft hybridization might occur via transfection (or transformation) of sex cells in the Yuhuang plum with genes derived from the purple-leaved plum through the sap circulating system. Understandably, no obvious changes were observed among the seedlings that grew from the seeds picked in 1998 and sown in 1999 because the floral buds had already formed during the grafting in 1998, and the sex cells were not transfected (or transformed) by the genes that derived from the purpleleaved plum through the sap circulating system. We cannot explain why the variant rate in 2000 was so high $(15.8 \%)$, but the grafted tree bore few fruits in that year and the fruit picking date was later than usual.

\section{ACKNOWLEDGMENTS}

We are deeply indebted to Dr. Kai Zhou and Guirong Li for reading the manuscript and for their comments and suggestions. Research supported by the Natural Science Fund of Henan Province (\#01110011600).

\section{REFERENCES}

Burbank L (1914-1915). His Methods and Discoveries and Their Practical Application. Luther Burbank Press, New York. Darwin C (1868). The Variation of Animals and Plants Under Domestication. John Murray, London.

Gahan PB (2003). Messenger DNA in higher plants. Cell Biochem. Funct. 21: 207-209.

Kanehira A, Yamada K, Iwaya T, Tsuwamoto R, et al. (2010). Apple phloem cells contain some mRNAs transported over long distances. Tree Genet. Genomes 6: 635-642.

Liu Y (2006). Historical and modern genetics of plant graft hybridization. Adv. Genet. 56: 101-129.

Michurin IV (1949). Selected Works. Foreign Languages Publishing House, Moscow.

Taller J, Yagishita N and Hirata Y (1999). Graft-induced variants as a source of novel characteristics in the breeding of pepper (Capsicum annuum L.). Euphytica 108: 73-78. 